\title{
Teatro da violência numa sociedade violenta
}

\author{
Katayoun Hosseinzadeh Salmasi
}

De acordo com Platão, deveríamos "banir o teatro pois este corrompe o governo e a política". Quando preparava a minha participação no presente seminário, revi centenas de casos, revistei os meus pensamentos e li a história do teatro do meu pais e do mundo, concluindo em desespero que não tinha absolutamente nada para apresentar. Como iraniana proveniente do Oriente, não tinha nada tangivel a acrescentar ao que já foi escrito. Pensei para mim mesma: qual seria a utilidade de repetir informação contida em livros que os próprios críticos e estudiosos teriam escrito e o que poderia eu adicionar de novo? Enquanto me debatia com este dilema, subitamente fez-se luz. Este era o meu problema principal e poderia ser igualmente o cerne da minha apresentação: numa sociedade em que prevalece a violência, poderá existir um teatro violento?

Para mim e para todos os que nasceram e vivem em países como o meu, a violência está profundamente enraizada na política. Além disso, recorda-nos a guerra, uma guerra que se tornou muito próxima. Muitos compatriotas têm sido mortos e os seus vizinhos enterrados sob os escombros de edifícios. Temos vivido momentos de ansiedade e medo, revolução, mudanças de governo, massacres, homicídios, aprisionamentos e muito mais. Que significado tem a violência para vós? Qual a vossa experiência relativamente à violência? Depois da Segunda Guerra Mundial, que muitos já não recordam, qual o sentido da ausência de violência num mundo próspero e livre? Se não experimentámos a violência individual, como perceber a violência de massas?

A diferença entre a violência individual e a violência

Katayoun Hosseinzadeh Salmasi

é doutoranda na

Universidade

Internacional de Tajikistan, Irão. Lecciona Teatro na

Art and Cultural University de Teerão. de massas consiste no facto de a primeira afectar uma pessoa, ou quando muito um grupo específico, penetrando num individuo ou grupo, por exemplo, um massacre numa escola, o assassínio de uma entidade importante, ou até desastres como o 11 de Setembro. Em relação à violência de massas, esta é infligida em toda uma sociedade pelo governo. Envolve todos os cidadãos do país e não há alternativa. A violência passa a fazer parte da vida do diaa-dia e é tão normal como respirar.

Reflectindo sobre a história, apercebi-me que antes da Idade Média, e mesmo depois dessa época, nos anos após a morte de Shakespeare, em Inglaterra, ou no século XVIII nas Américas e no século XIX na Alemanha, até ao momento presente, sempre houve épocas em que o teatro foi considerado um grande inimigo. No entanto, os governos tentaram sempre impedir, tanto quanto possivel, a expressão de violência efectiva. Em nenhuma das épocas em que a censura dominou o teatro houve algo semelhante ao teatro violento da contemporaneidade, nem ninguém que se tenha debruçado sistematicamente sobre esta temática. Pelo contrário, quanto mais livre a sociedade, mais visível se torna o teatro da violência. Mas até mesmo nestas sociedades livres surge uma questão pertinente, que enunciarei, mas que não poderei desenvolver aqui: em que medida e até onde poderá o teatro libertar-se de modo a servir de exemplo social? Se imaginássemos a encenação da violência sem quaisquer limites, até que ponto o público manteria o seu interesse pela peça?

Creio que o teatro se baseia em oposições. Pode dizer respeito a qualquer aspecto - política, sociedade, cultura, indústria, arte, tradição, ideologia, relações humanas, entre muitos outros aspectos. 0 cerne da questão consiste no facto de um artista necessitar de se opor a tendências destrutivas, quando é confrontado com elas, devendo tentar descobrir maneiras de expressar a sua opinião, mesmo se neutral.

É comum afirmar-se que não se pode imaginar o que nunca se viu. Deste modo, os artistas estarão certamente sob a influência da violência presente na sociedade a que pertencem, representando essa mesma violência. Mas se imaginarmos um artista que vive numa sociedade com restrições, este ver-se-á forçado a exprimir-se através de metáforas. Essas metafóras não vão apenas atenuar todas as suas opiniões, mas também irão diminuir qualquer efeito violento na sua arte. No entanto, por vezes, estas metáforas têm sido empregues pelo próprio governo em situações de extrema violência. Esta atitude tem levado os artistas a tentar encontrar um novo simbolismo, criando 


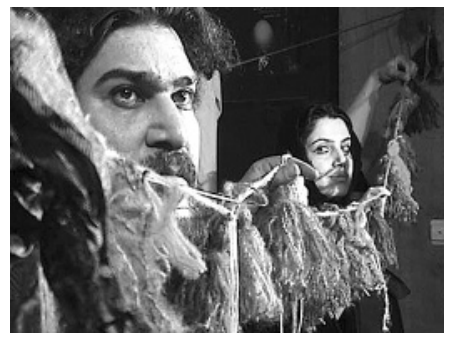

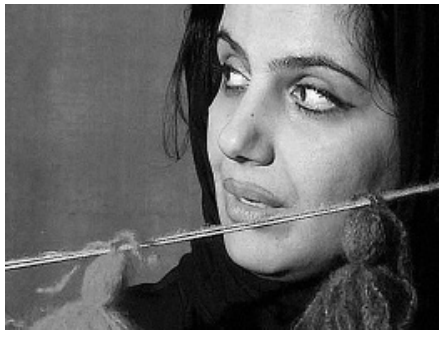

da violência o público é confrontado com a verdade que 0 afecta directamente.

Estas peças não podem ser encenadas numa sociedade sob o domínio de um governo autoritário, também não podendo constituir-se como uma resposta para a opinião pública. 0 teatro da violência é uma forma independente que não pode ser sujeita a limites existentes, podendo assim criar um movimento na sociedade. Não é sem razão que Platão proferiu o seu famoso comentário: "expulsem o teatro da cidade pois ele corrompe o governo e a política..."

Não obstante, o teatro da violência não pode perdurar numa sociedade em que a violência domine e ser simultaneamente benéfico para a política dessa mesma sociedade. Assim, as sociedades que permitem a representação da violência, já tiveram uma experiência anterior da mesma e, como resultado, atingiram um grau de libertação, enquanto que aquelas sociedades que vivem sob o efeito da violência não podem permitir a sua representação.

Por último, se não estiverem satisfeitos com a violência presente nos vossos palcos, ou se pensam que o teatro experimental nos está a conduzir para o desastre, e se estão convencidos de que toda a violência actual não tem sentido, profundidade, é revoltante e não tem qualquer justificação plausivel, ou mesmo se estiverem totalmente contra a violência no teatro, seja qual for a forma adoptada, poderão estar a votar a favor dos ditadores e fascistas dos vossos países. Em pouco tempo todos os obstáculos desaparecerão e não terão quaisquer problemas relacionados com o teatro da violência. Com efeito, o teatro violento terá emigrado do vosso país. Apresentar uma solução para este problema é assim perigosamente fácil!

Tradução de Ana Raquel Lourenço Fernandes
Well, texto e enc. Katayoun Hosseinzadeh Salmasi, House of Theatre Hall, Teerão, 2007 (Karamat Roodsaz e Parizad Saif), fot. Katayoun Hosseinzadeh Salmasi. crueldade das superpotências, não conseguindo também alterar o comportamento humano. A sua resposta à violência não teve qualquer impacto na sociedade pois a violência representada é, na verdade, muito diferente da representação, por vezes, distanciando-se tanto do seu público que as suas intenções são convertidas em pose intelectual. Pelo contrário, noutras comunidades violentas, peças semelhantes comunicam com o público.

0 teatro da violência apresenta acontecimentos e situações que afectam as pessoas. Se uma peça apresenta determinados acontecimentos e consegue analisar simultaneamente as suas razões, podemos então afirmar com confiança que prestou um grande serviço. No teatro 